\title{
Autosomal recessive isolated optic atrophy
}

INSERM

\section{Source}

INSERM. (1999). Orphanet: an online rare disease and orphan drug data base. Autosomal recessive isolated optic atrophy. ORPHA:98676

A rare hereditary optic atrophy characterized by an early onset of bilateral optic nerve degeneration without other systemic features. Clinical manifestations include pallor of the optic disks, severe but slowly progressing visual impairment, and in some patients also paracentral scotoma, photophobia and dyschromatopsia. 